\title{
PENERAPAN SANKSI TERHADAP PENYELUDUPAN BARANG ELEKTRONIK BERDASARKAN UU NOMOR 17 TAHUN 2006 TENTANG PERUBAHAN ATAS UU NOMOR 10 TAHUN 1995 TENTANG KEPABEANAN DI KOTA PEKAN BARU
}

\author{
Abdul Rifqi ${ }^{1}$ \\ Program Studi Magister Ilmu Hukum Universitas Lancang Kuning \\ Corresponding Author Email ${ }^{1}$ : abdurifaiabdul@gmail.com \\ Ardiansah $^{2}$ \\ Program Studi Magister Ilmu Hukum Universitas Lancang Kuning \\ Email2 : ardiansyah2000@yahoo.com \\ Aliar Syam ${ }^{3}$ \\ Program Studi Magister Ilmu Hukum Universitas Lancang Kuning \\ Email $^{3}$ : Aliarsyam@gmail.com \\ DOI: https://doi.org/10.31764/jmk.v11i2.3159
}

Received: Augt 20, 2020, Accepted: Sept 30, 2020 /Published: Okt 31, 2020

\begin{abstract}
Law Number 17 of 2006 concerning amendements to Law Number 10 of 1995 concerning custom, is expected to be present to solve problems in the cusmtoms and excise environment. Through the provisions of this rule, the regulation and control of the traffic of goods and services or know as customs, can be put in order. Electronic goods smuggling, one of the smuggling activities thatis rife in Riau Province, in addition to the smuggling would easily pass it. In Riau, the ports of Dumai and Bengkalis are the main ports, because most of the export and import activities of goods that enter and exit or go to neighboring countries, through these ports. This type of research is research conducted by identifying the law, how the effectiveness of the law applies in society. The imposition of sanctions against the smuggling of electronic goods has not yet been implemented properly. Because, during the inspection and proven to have committed a violation, the said goods and means of transportation are not brought and stored at the customs store for further examination, and the examination is not recorded in the Official Report of the Inspection The obstacle is the lack of number of personnel on duty at the Supervisory and Customs Service Office of Pekanbaru City, making it easier for suppliers of electronic goods to distribute their merchandise to the public. Lack of socialization to smugglers, regarding the application of customs laws, lack of coordination between agencies, both members of Customs and Excise and the Police, in enforcing the law against electronic smugglers
\end{abstract}

Keywords: application; smuggling; electronic goods. 


\begin{abstract}
ABSTRAK
Undang-Undang Nomor 17 Tahun 2006 tentang perubahan atas UndangUndang Nomor 10 Tahun 1995 tentang Kepabeanan, diharapkan hadir untuk menyelesaikan persoalan di lingkungan bea dan cukai. Melalui ketentuan aturan ini, pengaturan dan pengawasan masuknya lalu lintas barang dan jasa atau disebut kepabeanan, dapat ditertibkan. Penyelendupan barang-barang elektronik, salah satu kegiatan penyelundupan yang marak terjadi di Provinsi Riau, di samping penyelendupan barang-barang ilegal lainnya. Lintas laut dipilih, karena dirasa mudah dilalui oleh pelaku penyelundupan. Di Riau, pelabuhan Dumai dan Bengkalis menjadi pelabuhan induk, karena kebanyakan kegiatan ekspor dan impor barang yang masuk dan keluar dari atau menuju negara tetangga, melalui pelabuhan tersebut. Jenis penelitian ini adalah penelitian yang dilakukan dengan cara mengadakan identifikasi hukum, bagaimana efektivitas hukum itu berlaku dalam masyarakat. Penerapan sanksi terhadap penyelundupan barang-barang elektronik, belum berjalan sebagaimana mestinya. Karena, dalam pemeriksaan dan terbukti melakukan pelanggaran, barang dan sarana pengangkut tersebut tidak dibawa dan disimpan di tempat penimbunan pabean untuk pemeriksaan lebih lanjut, dan pemeriksaan tersebut tidak dituangkan kedalam Berita Acara Pemeriksaan. Hambatannya adalah, kurangnya jumlah personil yang bertugas di Kantor Pengawas dan Pelayanan Bea dan Cukai Kota Pekanbaru, sehingga memudahkan bagi pemasok barang elektronik dalam mengedarkan barang dagangannya ke masyarakat. Kurangnya sosialisasi terhadap pelaku penyelundupan, mengenai penerapan undang-undang kepabeanan, kurangnya koordinasi antar instansi, baik itu sesama anggota Bea dan Cukai maupun Kepolisian, dalam menegakan hukum kepada pelaku penyelundupan barang elektronik.
\end{abstract}

Kata Kunci : penerapan; penyelundupan; barang elektronik.

\title{
PENDAHULUAN
}

Dibentuknya Undang-Undang Nomor 17 tahun 2006 tentang Perubahan atas Undang-Undang Nomor 10 Tahun 1995, pemerintah berharap dapat mengatasi permasalahan di ruang lingkup bea cukai, khususnya pengaturan dan pengawasan masuknya lalu lintas barang dan jasa atau disebut kepabeanan. Pemberantasan tindak pidana penyelundupan melalui jalur laut, dilakukan oleh direktorat jendral bea dan cukai bersama Kepolisian Republik Indonesia. Direktorat jendral bea 
dan cukai dalam tugas dan fungsinya bukan hanya melakukan pemungutan bea masuk, cukai dan pungutan-pungutan lainnya, tetapi juga melaksanakan fungsi pengawasan serta penegakan hukum, yaitu pencegahan dan pemberantasan tindak pidana penyelundupan. Sebagaimana dituangkan dalam Pasal 7 ayat (2) KUHAP yang menentukan bahwa penyidik pegawai negeri sipil mempunyai wewenang sesuai dengan undang-undang yang menjadi dasar hukumnya serta dalam melaksanakan di bawah koordinasi dan pengawasan Penyidik Polisi Negara Republik Indonesia. Penyidik pegawai negeri sipil dalam menjalankan tugasnya tetap dibantu oleh penyidik POLRI. Dalam hal ini penyidik polri melakukan koordinasi,pengawasan, pemberian petunjuk, dan pemberian bantuan penyidik.

Sanksi pidana bagi seseorang yang melakukan tindak penyelundupan telah diatur dalam Pasal 102 Undang-Undang Nomor 17 tahun 2006 tentang Kepabeanan. Pasal 102 menegaskan, “dipidana karena melakukan penyelundupan di bidang ekspor dengan pidana penjara paling singkat 1 (satu) tahun dan pidana penjara paling lama 10 (sepuluh) tahun dan pidana denda paling sedikit Rp. 50.000 .000 (lima puluh juta rupiah) dan paling banyak Rp. 5.000.000.000,00 (lima miliar rupiah)".

Sanki administrasi bagi seorang yang melakukan penyelundupan diatur dalam Pasal 7A Undang-Undang Kepabeanan yang menegaskan, “pengangkut yang tidak memenuhi ketentuan sebagaimana dimaksud pada ayat (1) dikenai sanksi administrasi berupa denda paling sedikit Rp. 5.000.000,00 dan paling banyak Rp. 50.000.000,00”.

Di Riau, pelabuhan Dumai dan Bengkalis menjadi pelabuhan induk, karena kebanyakan kegiatan ekspor dan impor barang yang masuk dan keluar dari atau menuju negara tetangga, melalui pelabuhan tersebut. Dari Kota Dumai dan Bengkalis, barang yang masuk dari negara lain, kemudian didistribusikan ke kota-kota lain yang ada di Riau. Inilah 
mekanisme pendistribusian barang-barang yang diselundupkan, ke berbagai wilayah di Provinsi Riau.

Penyelundupan barang-barang elektronik yang terjadi petengahan bulan Maret tahun 2020, berhasil digagalkan Bea Cukai Bengkalis. Barang selundupan berupa 5 buah komputer jinjing, 7 buah telepon seluler, 6 buah kamera closed circuit television (CCTV), 1 buah amplifier, dan 1 buah monitor. ${ }^{1}$ Selanjutnya kantor eilayah Direktorat Jenderal Pajak Bea dan Cukai selama dalam tahun 2020, telah menindak penyelundupan barangbarang elektronik berupa telepon genggam, laptop, dan aksesoris, dengan total nilai Rp. 1,34 miliar. ${ }^{2}$ Melihat kasus yang terjadi sampai tahun 2020, di mana dalam tahun tersebut, pandemi covid-19, telah melanda berbagai negara di dunia, termasuk Indonesia. Kerja sama para penegak hukum, baik penyidik Polri maupun PPNS dalam hal ini Bea dan Cukai, dalam menyikapi kasus penyelundupan yang terjadi hingga saat ini. Dalam penyelesaian kasus penyelundupan barang elektronik di wilayah kepabeanan Kota Pekanbaru, dibutuhkan peran dari Pejabat Pegawai Negeri Sipil Bea dan Cukai dalam mengawasi penyelundupan barang elektronik tersebut.

\section{METODOLOGI}

Jenis penelitian adalah penelitian hukum sosiologis. Penelitian yang dilakukan dengan cara mengadakan identifikasi hukum bagaimana efektivitas hukum itu berlaku dalam masyarakat yang membahasas tentang Penerapan Sanksi Terhadap Penyeludupan Barang Elektronik Berdasarkan Undang-Undang Nomor 17 Tahun 2006 tentang perubahan atas Undang-Undang Nomor 10 Tahun1995 tentang Kepabeanan di Kota

\footnotetext{
1https://m.merdeka.com/uang/bea-cukai-bengkalis-gagalkan-penyelundupan-barang elektronik.html (Diakses pada hari Rabu tanggal 14 Oktober 2020 pukul 23.15 WITA).

2https:// riau.antaranesws.com/berita/174986/bea-cukai-riau-klaim-sita-rp331-miliar-barangilegal (Diakses pada hari Rabu tanggal 14 Oktober 2020 pukul 23.20 WITA).
} 
Pekanbaru. ${ }^{3}$ Metode pendekatan secara Empiris dilakukan terhadap bahan hukum non Undang-Undang4, dalam hal ini menguji dan mengkaji data sekunder yang berkaitan pendekatan Penerapan Sanksi Terhadap Penyeludupan Barang Elektronik Berdasarkan Undang-Undang Nomor 17 Tahun 2006 tentang perubahan atas Undang-Undang Nomor 10 Tahun 1995 tentang Kepabeanan di Kota Pekanbaru. Pendekatan penelitian ini bersifat deskriptif yaitu penulis mencoba untuk memberikan gambaran dari suatu kenyataan secara lengkap rinci, dan jelas tentang mengenai masalah yang diteliti. Pendekatan penelitian yang digunakan penulis dalam penelitian ini adalah menggunakan pendekatan Undang-Undang (Statue Approach)

\section{PEMBAHASAN}

\section{A.Penerapan Sanksi Terhadap Penyelundupan Barang Eletronik} Berdasarkan Peraturan Perundang-Undangan Di Kota Pekanbaru

Pasar bebas ilegal yang tumbuh subur di suatu negara yang mana barang-barang konsumsi sangat langka atau mahal karena dikenakan pajak. Pada jenis pertama, harga pasar gelap (black market) bisa jadi lebih tinggi dari harga 'resmi' atau yang dikendalikan oleh otoritas ekonomi negara. Pada jenis kedua, harga jadi lebih rendah dari harga 'sah' atau yang dikenakan pajak, karena penggelapan pajak." Dari definisi di atas yang banyak terjadi di Indonesia adalah jenis black market yang kedua; yaitu barang ilegal yang masuk ke dalam negeri dengan tanpa pembayaran pajak (bea). Yang awalnya barang itu mahal karena ada pajak yang dibayar, barang itu menjadi lebih murah bahkan sangat murah karena tidak terkena pajak. Walaupun memang definisi ini tidak disepakati oleh semua pihak, akan tetapi transaksi jenis black market di atas, memang yang banyak terjadi. Kabar yang banyak beredar di media

\footnotetext{
3 Soerjono Soekanto, Pengantar Penelitian Hukum, (Jakarta: UI-Press, 1982), hlm. 30.

4 Buku Pedoman Penulisan Tesis Universitas Lancang Kuning Tahun 2015.
} 
walaupun redaksi berbeda, akan tetapi intinya sama, yaitu penjualan barang ilegal karena tidak melewati pembayaran pajak. Artinya tidak melalui jalur yang sah, yang telah ditetapkan oleh suatu negara. Oleh karena itu, penjualan dan peredaran barang elektronik dari tahun ke tahun mengalami peningkatan dan perkembangan yang cukup besar. ${ }^{5}$ Tetapi perdagangan yang demikian dapat merugikan konsumen, karena konsumen merupakan pihak yang seringkali dirugikan dalam suatu hubungan kerjasama antara penjual dan pembeli. Kedudukan pelaku usaha dan konsumen tidak seimbang, di mana konsumen berada pada posisi yang lemah yang menjadi objek aktifitas bisnis untuk meraup keuntungan yang sebesar- besarnya oleh pelaku usaha. ${ }^{6}$

Berdasarkan Undang-Undang Nomor 17 Tahun 2006 tentang Perubahan Atas Undang-Undang Nomor 10 Tahun 1995 tentang Kepabeanan di Kota Pekanbaru, sumber pendapatan dari suatu daerah adalah salah satunya dari pajak dan retribusi. Pajak dan retribusi menjadi pendapatan yang sangat dibutuhkan oleh suatu daerah, demi kemajuan dan kesejahteraan daerah tersebut. Pungutan Daerah sebagai pembayaran atas jasa atau pemberian izin tertentu yang khusus disediakan dan/atau diberikan oleh Pemerintah Daerah, untuk kepentingan orang pribadi atau badan. Peraturan tentang retribusi dalam memberikan izin, namun masih ada orang atau badan usaha yang tidak melakukan pembayaran pajak atas barang ilegal yang dibawa masuk kedalam suatu daerah tersebut, sehingga menyebabkan kerugian terhadap pendapatan daerah tersebut. Undang-Undang Nomor 17 Tahun 2006 tentang Perubahan Atas Undang-Undang Nomor 10 Tahun 1995 Tentang Kepabeanan di Kota Pekanbaru bahwa sebelum melakukan penindakan terhadap

\footnotetext{
${ }^{5}$ Bagir Manan, Menegakkan Hukum, (Jakarta : Sinar Grafika, 2009), hlm. 51.

6 Edi Yanto et. al, "Perlindugan Hukum Konsumen Jasa Parkir ditinjau dari Hukum Positif", Jurnal Media Keadilan, Jurnal Hukum, Volume 11, No. 1 April, 2020, hlm. 112-128.
} 
penyelundupan barang eletronik ilegal Bea Cukai terlebih dahulu melakukan beberapa hal sebagai berikut:

1. Melakukan pengawasan dan penyegelan terhadap sarana pengangkut yang melakukan pelanggaran kepabenan, melakukan penangkapan dan penegahan terhadap sarana pengangkut yang dicurigai melakukan pelanggaran kepabeanan.

2. Melakukan penyidikan terhadap yang dicurigai melakukan pelanggaran tentang kepabeanan dan melakukan pemeriksaan terhadap barang impor ekspor setelah pemberitahuan pabean.

3. Pengusaha yang hendak melakukan kegiatan impor atau importir mengajukan permohonan impor kepada pihak bea dan cukai dimana dia akan melakukan kegiatan impor tersebut. Pengusaha tersebut mengajukan surat permohonan pabean, menyerahkan disket atau dokumen yang diperlukan untuk melakukan kegiatan impor tersebut. Ini dilakukan untuk mempermudah para importir melakukan kegiatan impor.

Peran lain yang dilakukan oleh Bea dan Cukai dalam melakukan pemeriksaan dokumen-dokumen pabean, yaitu dengan memeriksa dokumen yang diajukan oleh pengusaha atau importir, memeriksa Manifest In dan memeriksa disket yang diserahkan oleh importir atau pengusaha, agar memudahkan pemeriksaan di lapangan.

Hasil wawancara dengan Kepala Bea Cukai mengenai penerapan sanksi terhadap penyelundupan barang eletronik berdasarkan Undang-Undang Nomor 17 Tahun 2006 tentang Perubahan Atas Undang-Undang Nomor 10 Tahun 1995 Tentang Kepabeanan di Kota Pekanbaru bahwa dengan melakukan usaha preventif dan represif, usaha preventif merupakan suatu usaha untuk mencagah timbulnya penyelundupan dengan meniadakan sebab terjadinya. Hal ini merupakan tugas seluruh aparat Direktorat Jenderal Bea dan Cukai. Usaha preventif ini tercermin dalam usaha sebagaimana yang tercantum dalam fungsi Direktorat Penindakan dan Penyidikan, di mana fungsi pelaksanaan kebijakan teknis, pembinaan, pengendalian, bimbingan, maupun kordinasi dilakukan dalam rangka pencegahan terhadap pelanggaran peraturan perundang- 
undangan. Usaha represif merupakan usaha menanggulangi, mengambil tindakan lebih lanjut dari akibat terjadinya penyelundupan. ${ }^{7}$

Berdasarkan hasil wawancara dengan Kepala Satuan Reserse Kriminal mengenai penerapan sanksi terhadap penyelundupan barang eletronik berdasarkan Undang-Undang Nomor 17 Tahun 2006 tentang Perubahan Atas Undang-Undang Nomor 10 Tahun 1995 tentang Kepabeanan di Kota Pekanbaru bahwa :8

1. Terhadap perusahaan dan sarana pengangkut yang melakukan pelanggaran Kepabeanan dilakukan pemeriksaan atau penyidikan untuk mencari bukti-bukti terhadap pelanggarannya yang nantinya akan dibuat dalam Berita Acara Pemeriksaan (BAP). BAP ini dibuat oleh pejabat bea dan cukai yang isinya memuat identitas petugas bea dan cukai yang memeriksa dan perusahaan yang diperiksa.

2. Pemeriksaan dapat dilakukan kedua kalinya apabila hasil dari pemeriksaan pertama masih kurang atau terdapat kejanggalan. Pemeriksaan kedua kalinya ini juga dituangkan dalam berkas Berita Acara Pemeriksaan (BAP) bea dan cukai.

3. Setiap perusahaan atau sarana pengangkut yang atau diduga melakukan pelanggaran Kepabeanan wajib melalui pemeriksaan Kepabeanan untuk menentukan jenis pelanggarannya. Setelah jenis pelanggarannya diketahui, maka pihak bea dan cukai akan dapat menetukan sanksi apa yang akan dikenakan terhadap perusahaan atau sarana pengangkut tersebut.

Berdasarkan hasil wawancara dengan Penyidik Pegawai Negeri Sipil, mengenai penerapan sanksi terhadap penyelundupan barang eletronik berdasarkan Undang-Undang Nomor 17 Tahun 2006 tentang Perubahan Atas Undang-Undang Nomor 10 Tahun 1995 Tentang Kepabeanan di Kota Pekanbaru, bahwa pada saat diterbitkannya Undang-Undang Nomor 17 Tahun 2006 tentang Perubahan Atas Undang-Undang Nomor 10 Tahun 1995 tentang Kepabeanan, maka tugas ini manjadi tugas pokok aparat Direktorat Jenderal Bea dan Cukai, khususnya pada Direktorat Pencegahan dan Penyidikan Tindak Pidana Kepabeanan. Penyidik Pegawai Negeri Sipil (PPNS) Bea dan Cukai bertindak

\footnotetext{
7 Wawancara dengan Bapak Elfi Haris Kepala Bea Cukai, Hari Selasa Tanggal 11 Agustus 2020, di Kantor Pengawasan dan Pelayanan Bea Cukai .

8 Wawancara dengan Kepala Reserse Kriminal Polresta Pekanbaru Bapak Awaludin Syam, Hari Senin, Tanggal 24 Agustus 2020, di Kantor Polresta Pekanbaru.
} 
berdasarkan pada adanya laporan yang didapat dari seksi intelejen dan seksi pencegahan, untuk kemudian ditindaklanjuti ketahap penyidikan, dalam rangka penemuan alat bukti dan tersangkanya.

Untuk itu, Bea dan Cukai memiliki wewenang sebagai berikut : ${ }^{9}$

1. Menerima laporan atau keterangan dari seseorang tentang adanya tindak pidana di bidang Kepabeanan dan memanggil orang untuk didengar dan diperiksa sebagai tersangka atau saksi.

2. Meneliti, mencari dan mengumpulkan keterangan sehubungan dengan tindak pidana di bidang kepabeanan.

3. Melakukan penangkapan dan penahanan terhadap orang yang disangka melakukan tindak pidana di bidang kepabeanan.

4. Meminta keterangan dan bukti dari orang yang disangka melakukan tindak pidana di bidang kepabeanan.

5. Memotret dan/atau merekam melalui media audio visual terhadap orang, barang, sarana pengangkut, atau apa saja yang dapat dijadikan bukti adanya tindak pidana di bidang kepabeanan.

6. Memeriksa catatan dan pembukuan yang diwajibkan menurut undangundang ini dan memeriksa catatan dan pembukuan yang diwajibkan menurut undang-undang ini, dan pembukuan lainnya yang terkait mengambil sidik jari orang serta menggeledah rumah tinggal, pakaian, atau badan.

7. Menggeledah tempat atau sarana pengangkut dan memeriksa barang yang terdapat di dalamnya apabila dicurigai adanya tindak pidana di bidang kepabeanan dan menyita benda-benda yang diduga keras merupakan barang yang dapat dijadikan sebagai bukti sehubungan dengan tindak pidana di bidang kepabeanan, serta memberikan tanda pengaman dan mengamankan apa saja yang dapat dijadikan sebagai bukti sehubungan dengan tindak pidana di bidang kepabeanan.

8. Mendatangkan tenaga ahli yang diperlukan dalam hubungannya dengan pemeriksaan perkara tindak pidana di bidang kepabeanan, menyuruh berhenti orang yang disangka melakukan tindak pidana dibidang kepabeanan, serta memeriksa tanda pengenal diri tersangka.

9. Menghentikan penyidikan dan melakukan tindakan lain yang perlu untuk kelancaran penyidikan tindak pidana di bidang kepabeanan menurut hukum yang bertanggung jawab.

Berdasarkan hasil wawancara dengan beberapa orang pelaku

penyelundupan barang eletronik mengenai penerapan sanksi terhadap penyelundupan barang eletronik berdasarkan Undang-Undang Nomor

${ }^{9}$ Hasil wawancara dengan beberapa Penyidik Pegawai Negeri Sipil Bapak Nur Zisam dan Muhdi Al, Hari Kamis, Tanggal 13 Agustus 2020, di Kantor Bea Cukai. 
17 Tahun 2006 tentang Perubahan Atas Undang-Undang Nomor 10 Tahun 1995 tentang Kepabeanan di Kota Pekanbaru bahwa, dengan melakukan pemeriksaan sarana pengangkut dan barang di atasnya, pejabat bea dan cukai berwenang memasuki sarana pengangkut dan atau bagiannya, meminta surat atau dokumen yang berkaitan dengan sarana pengangkut dan atau barang diatasnya, memerintahkan sarana pengangkut untuk membuka kemasan atau barang yang dibawanya. Apabila tidak dipenuhi maka pejabat bea dan cukai berhak membuka kemasan atau barang yang dibawa tersebut. Setelah melakukan pemeriksaan dan terbukti melakukan pelanggaran kepabenan maka, barang dan sarana pengangkut tersebut dibawa dan disimpan di tempat penimbunan pabean untuk pemeriksaan lebih lanjut. Dari hasil pemeriksaan yang dilakukan oleh pejabat bea dan cukai terhadap sarana pengangkut dan barang yang ada diatasnya, maka pemeriksaan tersebut dituangkan kedalam Berita Acara Pemeriksaan yang ditandatangani oleh pejabat bea dan cukai bersama yang bertanggung jawab terhadap sarana pengangkut tersebut. Terhadap sarana pengangkut yang melakukan pelanggaran kepaebanan dilakukan pemeriksaan atau penyidikan untuk mencari bukti-bukti terhadap pelanggarannya yang nantinya akan dibuat dalan Berita Acara Pemeriksaan (BAP), BAP ini dibuat oleh pejabat bea dan cukai yang isinya antara lain memuat identitas petugas bea dan cukai yang memeriksa dan sarana pengangkut yang diperiksa. Apabila bukti sudah dianggap cukup maka perkara dapat langsung diajukan ke kejaksaan negeri setempat untuk proses lebih lanjut. ${ }^{10}$

Penerapan sanksi terhadap penyelundupan barang eletronik berdasarkan Undang-Undang Nomor 17 Tahun 2006 tentang Perubahan Atas Undang-Undang Nomor 10 Tahun 1995 tentang Kepabeanan di Kota

\footnotetext{
10 Wawancara dengan Beberapa Orang Pelaku Penyelundupan Barang Eletronik, Hari Kamis Tanggal 27 Agustus 2020, di Kantor Pengawasan dan Pelayanan Bea dan Cukai Kota Pekanbaru.
} 
Pekanbaru, belum berjalan sebagaimana mestinya. Hal ini dikarenakan dalam melakukan pemeriksaan dan terbukti melakukan pelanggaran, maka barang dan sarana pengangkut tersebut tidak dibawa dan disimpan di tempat penimbunan pabean untuk pemeriksaan lebih lanjut, tapi hanya dipanggil siapa pengusaha yang memiliki barang elektronik ini dan hasil pemeriksaan yang dilakukan oleh pejabat bea dan cukai terhadap barang elektronik ini pemeriksaan tersebut, tidak dituangkan kedalam Berita Acara Pemeriksaan. karena adanya kegiatan para pengusaha barang elektronik tersebut, memberikan sejumlah uang kepada oknum bea dan cukai yang terlibat dalam penyelundupan tersebut, serta kurangnya armada pendukung dan koordinasi sesama anggota dalam melakukan kegiatan penyelundupun barang elektronik tersebut.

\section{B. Upaya Mengatasi Hambatan dalam Penerapan Sanksi Terhadap Penyeludupan Barang Elektronik Berdasarkan Peraturan Perundang- Undangan di Kota Pekanbaru}

Bangsa Indonesia dewasa ini sedang melaksanakan pembangunan disegala bidang kehidupan, sesuai dengan keadaan negara yang sedang berkembang. Salah satunya pembangunan di bidang sosial, dengan tujuan untuk meningkatkan taraf hidup rakyat yang lebih baik secara materil, maupun secara spiritual agar tercapai derajat hidup yang setinggitingginya. Pembangunan di bidang ekonomi dan sosial agar tercapai dan berhasil, sesuai dengan apa yang telah dicita-citakan oleh bangsa Indonesia, maka sangat ditentukan oleh faktor sumber daya manusia, karena faktor sumber manusia memegang peran yang sangat penting. Berhubungan dengan itu untuk melaksanakan setiap usaha diperlukan sumber daya manusia yang ahli dan terampil, karena tidak mungkin seseorang dapat melaksanakan suatu pekerjaan tersebut jika seseorang 
tersebut tidak menguasai atau memiliki keahlian dan keterampilan di bidangnya. ${ }^{11}$

Kota Pekanbaru merupakan salah satu kota yang perkembangannya sangat pesat dari tahun ke tahun. Di antaranya perkembangan infrasturktur dan perkembangan di bidang ekonomi. Faktor ekonomi merupakan faktor yang paling mendasar berkembangnya suatu negara, tidak ada suatu negara pun yang maju dan sukses jika perekonomiannya tidak baik. Dengan perekonomian yang mapanlah suatu negara itu dapat menjalankan roda pemerintahan dan mengatur kehidupan rakyatnya dengan baik, sehingga dapat berkembang dan maju. Tidak ada satu negarapun yang menginginkan rakyatnya sengsara, dan tidak ada manusia yang ingin hidup sengsara dan susah, dan itu sudah menjadi kodrat manusia. Hal ini sesuai dengan tujuan negara Indonesia, yaitu untuk meningkatkan kemakmuran rakyat secara menyeluruh, maka untuk itu pertumbuhan ekonomi harus ditingkatkan, dan untuk meningkatkan pertumbuhan ekonomi dibutuhkan kekuatan dan tenaga dari suatu negara secara kolektif. ${ }^{12}$

Berdasarkan hasil wawancara dengan Kepala Inspektorat Kantor Wilayah Kementrian Keuangan Provinsi Riau, mengenai hambatan dalam penerapan sanksi terhadap penyelundupan barang eletronik berdasarkan Undang-Undang Nomor 17 Tahun 2006 tentang Perubahan Atas UndangUndang Nomor 10 Tahun 1995 entang Kepabeanan di Kota Pekanbaru bahwa kurang tegasnya sanksi yang diberikan kepada pelaku penyelundupan barang eletronik, sehingga para pelaku tidak jera dalam

11 Usman Arifin, Kebijakan dan Administrasi Publik, (Jakarta: Gramedia Pustaka Utama, 2003), hlm. 35 .

12 Sumantoro, Aspek-Aspek Pidana di Bidang Ekonomi, (Jakarta : Ghalia Indonesia, 2000), hlm. 86. 
menyelundupkan barang eletronik yang telah merugikan pendapatan daerah dari sektor pajak. ${ }^{13}$

Berdasarkan hasil wawancara dengan Kepala Penindakan Bea Cukai, mengenai hambatan dalam penerapan sanksi terhadap penyelundupan barang eletronik berdasarkan Undang-Undang Nomor 17 Tahun 2006 tentang Perubahan Atas Undang-Undang Nomor 10 Tahun 1995 tentang Kepabeanan di Kota Pekanbaru, bahwa kurangnya pengawasan dan penyegelan terhadap sarana pengangkut yang melakukan pelanggaran kepabenan, melakukan penangkapan dan penindakan, terhadap sarana pengangkut yang dicurigai melakukan pelanggaran kepabeanan, serta masih lemahnya penanganan dalam penindakan terhadap penyelundupan barang eletronik ilegal. ${ }^{14}$

Berdasarkan hasil wawancara dengan Kepala Bea Cukai mengenai hambatan dalam penerapan sanksi terhadap penyelundupan barang eletronik berdasarkan Undang-Undang Nomor 17 Tahun 2006 tentang Perubahan Atas Undang-Undang Nomor 10 Tahun 1995 tentang Kepabeanan di Kota Pekanbaru adalah: ${ }^{15}$

1. Kurangnya sarana dan prasarana seperti kapal patroli, speed boat dan armada lainnya (hanya berjumlah 1 unit), sebagai alat transportasi untuk melakukan pengawasan terhadap kegiatan penyelundupan barang elektronik ini.

2. Kurangnya jumlah personil yang bertugas di lapangan dalam melakukan patroli. Kantor Pengawas dan Pelayanan Bea Cukai hanya memiliki 10 pesonil, sehingga memudahkan bagi pemasok barang eletronik dalam mengedarkan barang dagangannya ke masyarakat.

3. Kurangnya sosialisasi terhadap pelaku penyelundupan barang elektronik mengenai penerapan Undang-Undang Nomor 17 Tahun 2006 tentang Kepabeanan, sehingga kurangnya kesadaran dari pelaku

\footnotetext{
${ }^{13}$ Hasil wawancara dengan Bapak Sigit Juli Hendriawan, Hari Rabu, Tanggal 26 Agustus 2020, di Kantor Inspektorat Wilayah Kementrian Keuangan Provinsi Riau.

14 Hasil wawancara dengan Bapak Arif Rifani Kepala Bagian Penindakan Bea Cukai, Hari Selasa Tanggal 11 Agustus 2020, di Kantor Pengawasan dan Pelayanan Bea dan Cukai.

15 Hasil wawancara dengan Bapak Elfi Haris Kepala Bea Cukai, Hari Selasa Tanggal 11 Agustus 2020, di Kantor Pengawasan dan Pelayanan Bea Cukai .
} 
penyelundupan barang elektronik ini untuk menjalankan aturan pemerintah yang telah ditetapkan.

Berdasarkan hasil wawancara dengan Kepala Satuan Reserse Kriminal Polresta Pekanbaru, mengenai hambatan dalam penerapan sanksi terhadap penyelundupan barang eletronik berdasarkan UndangUndang Nomor 17 Tahun 2006 tentang Perubahan Atas Undang-Undang Nomor 10 Tahun 1995 tentang Kepabeanan di Kota Pekanbaru. Narasumber menjelaskan, kurangnya sarana dan prasarana, masih belum memadai baik yang menyangkut peralatan untuk pengawasan, perlengkapan dan fasilitas harus dibenahi dan dilengkapi untuk meningkatkan kinerja dan pelayanan kepada masyarakat. ${ }^{16}$

Berdasarkan hasil wawancara dengan beberapa pelaku penyelundupan barang eletronik, mengenai hambatan dalam penerapan sanksi terhadap penyelundupan barang eletronik berdasarkan UndangUndang Nomor 17 Tahun 2006 tentang Perubahan Atas Undang-Undang Nomor 10 Tahun 1995 tentang Kepabeanan di Kota Pekanbaru bahwa:17

1. Kurangnya sosialisasi terhadap pelaku penyelundupan barang elektronik ini, mengenai penerapan Undang-Undang Nomor 17 Tahun 2006 tentang Kepabeanan, sehingga kurangnya kesadaran dari penyelundup barang eletronik untuk menjalankan aturan pemerintah yang telah ditetapkan.

2. Kurangnya jumlah personil yang bertugas, yang dimiliki oleh Kantor Pengawas dan Pelayanan Bea dan Cukai Kota Pekanbaru dalam melayani barang yang masuk, sehingga memudahkan bagi pemasok barang eletronik dalam mengedarkan barang dagangannya ke masyarakat.

Hambatan dalam penerapan sanksi terhadap penyelundupan barang eletronik, berdasarkan Undang-Undang Nomor 17 Tahun 2006 tentang Perubahan Atas Undang-Undang Nomor 10 Tahun 1995 tentang

\footnotetext{
16 Hasil wawancara dengan Kepala Reserse Kriminal Polresta Pekanbaru Bapak Awaludin Syam, Hari Senin, Tanggal 24 Agustus 2020, di Kantor Polresta Pekanbaru.

17 Hasil wawancara dengan Beberapa Orang Pelaku Penyelundupan Barang Eletronik, Hari Kamis Tanggal 27 Agustus 2020, di Kantor Pengawasan dan Pelayanan Bea dan Cukai Kota Pekanbaru.
} 
Kepabeanan di Kota Pekanbaru, yaitu kurangnya sosialisasi terhadap pelaku penyelundupan mengenai penerapan Undang-Undang Nomor 17 Tahun 2006 tentang Kepabeanan. Hambatan lainnya yang dapat disimpulkan oleh penulis, yaitu kurangnya koordinasi antar instansi baik itu sesama anggota Bea dan Cukai maupun Kepolisian, dalam menegakan hukum kepada pelaku penyelundupan barang elektronik ini, sehingga terhambatnya pelaksanaan tugas-tugas baik anggota Bea dan Cukai, maupun dari kepolisian itu sendiri.

Tugas untuk membenahi sistem hukum yang sudah sedemikian rupa kebablasan dan tenggelam dalam arus vested interest, adalah suatu keharusan yang tidak terelakkan, dan merupakan suatu tugas berat bagi generasi mendatang, khususnya para mahasiswa hukum, intelektual hukum, maupun praktisi hukum, serta aparatur hukum. Pembenahan sektor hukum merupakan hal prioritas jika saja kita mau belajar dari kejayaan dan keruntuhan pengalaman pemerintahan masa lalu. Selanjutnya pada tahapan berikutnya adalah melakukan pembenahan sumber daya manusia (SDM) yang profesional dalam bidang hukum dan berorientasi masa depan. ${ }^{18}$

Besarnya daya serap pasar terhadap penjualan barang elektronik ilegal di Indonesia, telah memberikan banyak kesempatan bagi para distributor untuk saling bersaing, menyalurkan dan memasarkan barang dagangannya yang telah diproduksi oleh produsen ke dalam pangsa pasar dalam masyarakat. Tentu saja, hal ini telah menciptakan suatu persaingan yang tinggi bagi para distributor, sehingga para distributor barang elektronik banyak yang tidak mampu bersaing secara sehat, melakukan peindustrian secara ilegal, seperti mendistribusikan barangnya dengan cara menghindari pajak. Salah satu cara ini, dapat memberikan

\footnotetext{
37.

18 Soerjono Soekanto, Teori Sosiologi Tentang Struktur Masyarakat, (Jakarta: Rajawali, 1986), hlm.
} 
manfaat bagi distributor dalam melakukan penekanan pangsa pasar ke dalam masyarakat dengan cepat, mudah dan murah, tanpa mengurangi keuntungan yang diperoleh oleh para distributor itu sendiri. ${ }^{19}$

Secara umum, barang elektronik ilegal (selundupan) sangat berbeda dengan barang resmi, atau yang biasa disebut barang legal. Pada hakikatnya barang eletronik ilegal, merupakan barang yang sengaja diselundupkan ke dalam negeri, dengan cara menghindari sistem perpajakan negara. Sedangkan barang elektronik legal merupakan barang yang didistribusikan melalui distributor resmi, yang memiliki kerja sama penjualan, atau pasca penjualan dengan produsen, serta telah memenuhi standar minimum yang telah ditentukan oleh pemerintah. ${ }^{20}$

Hasil wawancara dengan Kepala Inspektorat Kantor Wilayah Kementrian Keuangan Provinsi Riau mengenai upaya yang dilakukan dalam mengatasi hambatan, serta penerapan sanksi terhadap penyelundupan barang eletronik berdasarkan kepabeanan di Kota Pekanbaru, narasumber menjelaskan, bahwa seharusnya adanya sanksi yang tegas diberikan oleh Pemerintah, terhadap pelaku dan pengusaha yang menjual barang eletronik ilegal, sehingga tidak menjadi kerugian bagi kas daerah dan pendapatan daerah. ${ }^{21}$

Hasil wawancara dengan Kepala Penindakan Bea Cukai mengenai upaya yang dilakukan untuk mengatasi hambatan dalam penerapan sanksi terhadap penyelundupan barang eletronik, berdasarkan UndangUndang Nomor 17 Tahun 2006 tentang Perubahan Atas Undang-Undang Nomor 10 Tahun 1995 tentang Kepabeanan di Kota Pekanbaru, narasumber menjelaskan, kurangnya pengawasan dan penyegelan terhadap sarana pengangkut yang melakukan pelanggaran kepabenan,

\footnotetext{
19 Yudi Wibowo, Tindak Pidana Penyelundupan di Indonesia, (Jakarta: Sinar Grafika, 2013), hlm. 6. ${ }^{20}$ Ibid., hlm. 8

${ }^{21}$ Hasil wawancara dengan Bapak Sigit Juli Hendriawan, Hari Rabu, Tanggal 26 Agustus 2020, di Kantor Inspektorat Wilayah Kementrian Keuangan Provinsi Riau.
} 
melakukan penangkapan dan penegahan terhadap sarana pengangkut yang dicurigai melakukan pelanggaran kepabeanan, serta masih lemahnya penanganan dalam penindakan terhadap penyelundupan barang eletronik ilegal.22

Hasil wawancara dengan Kepala Bea Cukai mengenai upaya yang dilakukan dalam mengatasi hambatan dalam penerapan sanksi terhadap penyelundupan barang eletronik, berdasarkan undang-undang kepabeanan di Kota Pekanbaru, dijelaskan bahwa perlunya penambahan jumlah personil yang bertugas di Kantor Pengawasan dan Pelayanan Bea Cukai, sehingga menutup ruang bagi pelaku penyelundupan barang eletronik ilegal, dalam mengedarkan barang dagangannya ke masyarakat. Selanjutnya, lebih meningkatkan sosialisasi terhadap Anggota Bea Cukai Pekanbaru dan pelaku penyelundupan barang eletronik ilegal sehingga tidak terjadi kembali. ${ }^{23}$

Berdasarkan hasil wawancara dengan Kepala Satuan Reserse Kriminal Polresta Pekanbaru, mengenai upaya yang dilakukan dalam mengatasi hambatan dalam penerapan sanksi terhadap penyelundupan barang eletronik berdasarkan undang-undang kepabeanan di Kota Pekanbaru, narasumber menjelaskan perlunya peningkatan sarana dan prasarana yang masih belum memadai, baik yang menyangkut peralatan untuk melakukan patroli di lapangan, maupun perlengkapan dan fasilitas untuk meningkatkan kinerja, guna memaksimalkan pengawasan terhadap penyelundupan barang eletronik ilegal.

Upaya selanjutnya yang diperlu dilakukan adalah, penambahan jumlah personil yang bertugas di Kantor Pengawasan dan Pelayanan Bea Cukai, sehingga menutup ruang bagi pelaku penyelundupan barang

\footnotetext{
${ }^{22}$ Hasil wawancara dengan Bapak Arif Rifani Kepala Bagian Penindakan Bea Cukai, Hari Selasa Tanggal 11 Agustus 2020, di Kantor Pengawasan dan Pelayanan Bea dan Cukai.

${ }^{23}$ Hasil wawancara dengan Bapak Elfi Haris Kepala Bea Cukai, Hari Selasa Tanggal 11 Agustus 2020, di Kantor Pengawasan dan Pelayanan Bea Cukai .
} 
eletronik ilegal, serta melakukan sosialisasi peraturan kepabean guna meningkatkan kesadaran masyarkat, khususnya pelaku penyelundupan barang eletronik ilegal tersebut, sehingga meminimalisir tindak pidana penyelundupan barang eletronik ilegal. ${ }^{24}$

Hasil wawancara dengan Penyidik Pegawai Negeri Sipil Bea Cukai mengenai upaya yang dilakukan dalam mengatasi hambatan dalam penerapan sanksi terhadap penyelundupan barang eletronik berdasarkan undang-undang kepabeanan di Kota Pekanbaru, yaitu perlunya penambahan jumlah personil yang bertugas di Kantor Pengawas, dan meningkatkan sosialisasi terhadap Anggota Bea Cukai dan pelaku penyelundupan barang eletronik ilegal mengenai penerapan Undang-Undang Nomor 17 Tahun 2006 tentang Perubahan Atas UndangUndang Nomor 10 Tahun 1995 tentang Kepabeanan, sehingga memberikan kesadaran dari pelaku penyelundupan ini, untuk menjalankan aturan pemerintah yang telah ditetapkan. ${ }^{25}$

Hasil wawancara beberapa pelaku penyelundupan barang elektronik illegal, mengenai upaya yang dilakukan dalam mengatasi hambatan dalam penerapan sanksi terhadap penyelundupan barang eletronik berdasarkan Undang-Undang Nomor 17 Tahun 2006 tentang Perubahan Atas UndangUndang Nomor 10 Tahun 1995 tentang Kepabeanan di Kota Pekanbaru, disebutkan bahwa perlu diadakan pembekalan bagi pemilik Kapal Motor yang berada di wilayah perairan Provinsi Riau, sehingga mengetahui undang-undang tentang kepabeanan. Selanjutnya, Pemerintah Daerah Provinsi Riau dan pihak berwenang lainnya, perlu melalukan sosialisasi dengan mengundang masyarakat dan perusahaan mengenai dampak serta masalah yang akan timbul, apabila penyelundupan terus menerus dibiarkan. Disinilah peran bea cukai mensosialisasikan, mengenai masalah yang akan timbul apabila terjadi

\footnotetext{
24 Hasil wawancara dengan Kepala Reserse Kriminal Polresta Pekanbaru Bapak Awaludin Syam, Hari Senin, Tanggal 24 Agustus 2020, di Kantor Polresta Pekanbaru.

${ }^{25}$ Hasil wawancara dengan beberapa Penyidik Pegawai Negeri Sipil Bapak Nur Zisam dan Muhdi Al, Hari Kamis, Tanggal 13 Agustus 2020, di Kantor Bea Cukai.
} 
penyeludupan barang eletronik illegal, terhadap perusahaan atau masyarakat yang akan melakukan kegiatan ekspor impor. ${ }^{26}$

Berdasarkan pengamatan dan analisis penulis mengenai upaya yang dilakukan dalam mengatasi hambatan dalam penerapan sanksi, terhadap penyelundupan barang eletronik berdasarkan Undang-Undang Nomor 17 Tahun 2006 tentang Perubahan Atas Undang-Undang Nomor 10 Tahun 1995 tentang Kepabeanan di Kota Pekanbaru, aturan tersebut hendaknya dapat memberikan kesadaran dari pelaku penyelundupan agar menjalankan aturan pemerintah yang telah ditetapkan, karena akan ada sanksi dari undang-undang kepabean, terhadap pelanggaran dan kejahatan (penyelundupan) yang dilakukan. Para penegak hukum, harus menjalankan aturan dan menegakan hukum, sesuai dengan ketentuan yang berlaku. Memberikan penindakan yang tegas terhadap pelaku penyelundupan barang-barang elektronik, tanpa tebang pilih. Mengadakan seminar-seminar tentang Kepabeanan yang diadakan Pemerintah Kota Pekanbaru dan pihak Bea dan Cukai Kota Pekanbaru serta pihak berwenang lainnya, dengan mengundang masyarakat dan perusahaan untuk memberikan edukasi mengenai masalah yang akan timbul apabila penyeludupan terus menerus dibiarkan. Kerugian yang diakibatkan oleh kegiatan penyelundupan barang-barang ilegal ke suatu wilayah/daerah, bukan saja akan dialami pemeritntah daerah, tetapi kerugian juga akan dialami oleh masyarakat maupun pengusaha.

\section{SIMPULAN}

Penerapan sanksi terhadap penyelundupan barang eletronik berdasarkan Undang-Undang Nomor 17 Tahun 2006 tentang Perubahan Atas UndangUndang Nomor 10 Tahun 1995 tentang Kepabeanan di Kota Pekanbaru, belum berjalan sebagaimana mestinya. Dalam melakukan pemeriksaan dan terbukti

\footnotetext{
${ }^{26}$ Hasil wawancara dengan Beberapa Orang Pelaku Penyelundupan Barang Eletronik, Hari Kamis Tanggal 27 Agustus 2020, di Kantor Bea Cukai
} 
melakukan pelanggaran, barang dan sarana pengangkut tersebut tidak dibawa dan disimpan di tempat penimbunan pabean untuk pemeriksaan lebih lanjut, tapi hanya dipanggil siapa pengusaha yang memiliki barang elektronik tersebut. Kemudian, hasil pemeriksaan yang dilakukan oleh pejabat bea dan cukai terhadap barang elektronik tersebut, tidak dituangkan kedalam Berita Acara Pemeriksaan. Hambatan dalam penerapan sanksi terhadap penyelundupan barang eletronik di Kota Pekanbaru, adalah kurangnya jumlah personil yang bertugas di Kantor Pengawas dan Pelayanan Bea dan Cukai Kota Pekanbaru, sehingga memudahkan bagi pemasok barang elektronik dalam mengedarkan barang dagangannya ke masyarakat. Kurangnya sosialisasi terhadap pelaku penyelundupan ini mengenai penerapan Undang-Undang Nomor 17 Tahun 2006 tentang Kepabeanan. Upaya yang dilakukan dalam mengatasi hambatan dalam penerapan sanksi terhadap penyelundupan barang eletronik berdasarkan undang-undang kepabeanan di Kota Pekanbaru, yaitu meningkatkan kualitas sumber daya manusia yang mumpuni, terlatih serta agar dapat menjalankan tugas dan fungsinya dengan baik.

\section{DAFTAR PUSTAKA}

\section{Buku}

Arifin, Usman, 2003, Kebijakan dan Administrasi Publik, Jakarta:Grameda Pustaka Utama.

Buku Pedoman Penulisan Tesis, 2015, Universitas Lancang Kuning.

Manan, Bagir, 2009, Menegakkan Hukum, Jakarta : Sinar Grafika.

Soekanto, Soerjono, 1986, Teori Sosiologi Tentang Struktur Masyarakat, Jakarta: Rajawali.

Soekanto, Soerjono , 1982, Pengantar Penelitian Hukum, Jakarta: UI-Press.

Sumantoro, 2000, Aspek-Aspek Pidana di Bidang Ekonomi, Jakarta:Ghalia Indonesia.

Wibowo, Yudi, 2013, Tindak Pidana Penyelundupan di Indonesia, Jakarta: Sinar Grafika. 


\section{Jurnal}

Edi Yanto et. al, “Perlindugan Hukum Konsumen Jasa Parkir Ditinjau Dari Hukum Positif", Jurnal Media Keadilan, Jurnal Hukum, Volume 11, No. 1 April, 2020, hlm. 112-128.

Erdianto, "Makelar Kasus/Mafia Hukum, Modus Operandi dan Faktor Penyebabnya", Jurnal Ilmu Hukum, Fakultas Hukum Universitas Riau, Edisi I, No. 1, Agustus 2010.

Widia Edorita, “Menciptakan Sebuah Sistem Hukum Yang Efektif :

Dimana Harus Di Mulai?" Jurnal Ilmu Hukum, Fakultas Hukum Universitas Riau, Edisi I, No. 1, Agustus 2010.

\section{Peraturan Perundang-Undangan}

Undang-Undang Nomor 17 Tahun 2006 tentang kepabeanan

Peraturan Pemerintah Nomor 55 Tahun 1996 tentang Penyidikan Tindakan Pidana Bidang Kepabeanan dan cukai, LN Nomor 85 Tahun 1996.

\section{Internet}

https://m.merdeka.com/uang/bea-cukai-bengkalis-gagalkanpenyelundupan-barang-elektronik.html https:/ / riau.antaranesws.com/ berita/174986/ bea-cukai-riau-klaim-sitarp331-miliar-barang-ilegal 